\title{
LEAN MANAGEMENT CONCEPT IN HOSPITAL MANAGEMENT - POSSIBILITIES AND LIMITATIONS
}

\author{
Renata Brajer-Marczak \\ Wrocław University of Economics, Wrocław, Poland \\ e-mail: renata.brajer-marczak@ue.wroc.pl
}

\section{Andrzej Wiendlocha}

Wrocław University of Economics, Wrocław, Poland

e-mail: aw@wamet.com

(C) 2017 Renata Brajer-Marczak, Andrzej Wiendlocha

This is an open access article distributed under the Creative Commons Attribution-NonCommercial-NoDerivs license (http://creativecommons.org/licenses/by-nc-nd/3.0/)

DOI: $10.15611 / \mathrm{ms} .2018 .1 .01$

JEL Classification: I0, M11, M12, O15, O31

\begin{abstract}
With reference to the current situation of national public hospitals, the article presents the possibility to implement the Lean Management concept in hospital management. Numerous common features connecting the management of commercial entities with the management of healthcare institutions are indicated. It has been stated that the management of contemporary organizations, regardless of the type of conducted operations, needs to focus on customer/patient satisfaction, financial liquidity and high quality. The purpose of the article is to assess the possibility to implement the Lean Management concept in hospitals. In particular, an attempt was made on the basis of a pilot survey to assess the introduction of the above concept in two selected hospitals. Critical analysis of the literature on the subject, the analysis of research results of other authors, casual interview, observation of practice as well as a survey based on the prepared questionnaire were used to achieve the purpose.
\end{abstract}

Keywords: Lean Management, Lean Health Care, process improvement

\section{Introduction}

The Lean Management concept as well as the application of its tools is presented mostly in the context of the needs of large and medium internal extensive production companies. Meanwhile, the observation of various entities functioning in the environment makes it possible to state that the objectives and principles on which the introduction of the concept is based may also be introduced in service-oriented organizations, including entities providing healthcare services ${ }^{1}$. When analyzing the process of providing healthcare services, in particular in public hospitals in Poland, the existence of the great potential for the application of this concept may be suggested. Public medical facilities, functioning with limited financial resources and the increased demand for the offered services (greater health awareness, ageing of the society and others), are looking today for methods to increase the effectiveness of their operations [Szewieczek 2013, p. 629]. At the same time, patients are more aware and their satisfaction from treatment also comes to the forefront. The focus of hospital processes on the patients' - customers' needs becomes more and more obvious. In turn, public healthcare institutions have less freedom to differentiate the provided services as compared to non-public entities (they are less competitive in this field), the costs of their functioning are high, the wastage of various resources (including time) and the rigidity of decision-making

${ }^{1}$ The concept was first introduced in the first decade of the 21st century by hospitals in Great Britain and the United States of America, publications also contained the notion of Lean Health Care. 
processes is visible, which may be considered an argument supporting the improvement of processes and the introduction of Lean Management, a concept fostering an increase in flexibility as well as enabling the optimization of the implemented processes, at the same time focusing the operations on the high quality of the provided healthcare services.

The purpose of this paper is to present the possibility to implement the Lean Management concept in hospitals. In particular, an attempt was made on the basis of a pilot survey to assess the possibility to introduce the above concept in two selected hospitals. The paper is based on a critical literature review, an unstructured interview, the observation of practice as well as a survey based on the prepared questionnaire were all used when preparing the article.

\section{Hospital services in Polish healthcare system}

The hospital is a healthcare facility consisting of asset components through which a healthcare institution performs a specific type of healthcare operations. Such a definition is provided by ${ }^{2}$ the Polish Act on healthcare operations amended on June 10, 2016 [Ustawa z dnia 15 kwietnia 2011 r. o działalności leczniczej 2016]. Hospital services include comprehensive health services performed 24 hours a day consisting of diagnosing, treating, nursing and rehabilitation which cannot be implemented as part of other stationary and round-the-clock healthcare or out-patient healthcare services [Ustawa $\mathrm{z}$ dnia 15 kwietnia 2011 r. o działalności leczniczej, item 618]. These benefits also include: invasive procedures, nursing, clinical study. Services provided by hospitals, the so-called healthcare services, may be defined as every healthcare service which, pursuant to the Polish Act dated April 15, 2011 on healthcare operations, means "actions aimed at preserving, saving, restoring or improving health as well as other medical operations resulting from the treatment process or from separate regulations governing the principles for their execution" [Ustawa $\mathrm{z}$ dnia 15 kwietnia 2011 r. o działalności leczniczej]. A hospital is an extremely complex institution producing a large number of various products, from basic services, e.g. accepting patients, to procedures requiring the highest specialization possible, e.g. organ transplants [Getzen 2000 , p. 231]. Operations conducted by hospitals are characterized by specific features. They may include:

- the standardization and measurement of work results which is significantly more difficult than in other trades,

- the diversity and complex nature of the performed work, often its suddenness,

- the need to coordinate activities between various professional groups, organizational units,

- the high specialization of employees,

- a strong sense of community and professional autonomy of medical employees: nurses and doctors, with different mentality and way of thinking, the so-called clinical mentality (quick, short-term actions with the patients) [Jończyk 2012, p. 197].

The cost structure of healthcare services indicates that care in hospitals is now the dominant component of all costs incurred for health services financed from NFZ (Polish National Health Fund) resources [NIK Report 2015]. At the same time, the quality of services provided by hospitals ${ }^{3}$ still leaves much to be desired from the perspective of the patients. Hospitals should undoubtedly aim at increasing the quality of provided services both in the technical and in the functional aspect [Ludwiczak 2017, p. 207]. On the one hand, they need to focus on understanding the patient's needs and expectations and, on the other, they should focus on the high effectiveness of their operations. The problem in the functioning of hospitals is, on the one hand, limited access to financial resources and, on the other hand, the constantly growing demand for healthcare services related to the ageing of the society, growing health awareness, the development of modern treatment technologies and techniques making it possible to treat diseases which were previously unknown, incurable or non-present (e.g. civilization diseases) [Szewieczek 2013, p. 630]. Hospitals financing their operations from public funds cannot use pricing methods based on incurred costs by increasing them by the assumed margin level, because the price (and, in principle, the fee) is determined by the payer (rather than by the market and the law of

\footnotetext{
2 The notion of a hospital was previously defined in the Polish Act dated April 15, 2011 on healthcare operations. The amendment from June 2016 repealed, first of all, the identification of the hospital with an enterprise and introduced the notion of a healthcare facility.

${ }^{3}$ Quality in healthcare may be analyzed from various perspectives, namely: technical competences, clinical results, but also in terms of the effectiveness of generated costs, the profitability of services or the undertaken risk - the payer's perspective. Matters particularly important for the patient include the availability of certain services, the waiting time for a service, methods of communication with the patient and the family. It is thus a subjective assessment of the recipient of services, namely how they perceive the quality level of the received service in the context of their earlier experience, or as compared to other institutions known to them for the services of which they used or heard about.
} 
demand and supply which traditionally happens in the market system). The need to "adjust" to the evaluation of healthcare services makes the executives in hospitals reduce those costs most heavily experienced by the patients - the recipients of the services. Currently $4.7 \%$ from the state budget is spent on healthcare, half the amount as compared to the majority of European countries, especially in Western Europe [NIK Report 2015]. Figure 1 presents the assessment of healthcare quality in Europe. The report drawn up by the Health Consumer Powerhouse ${ }^{4}$ shows how the quality of healthcare services offered in national institutions differs from the quality of services offered in other European countries. Countries with a high level of healthcare services, where they are being improved all the time, are marked in green. Yellow represents countries with a constantly improving quality of healthcare services, while red marks countries where the quality of healthcare services is improving but was below the European average in 2016 .

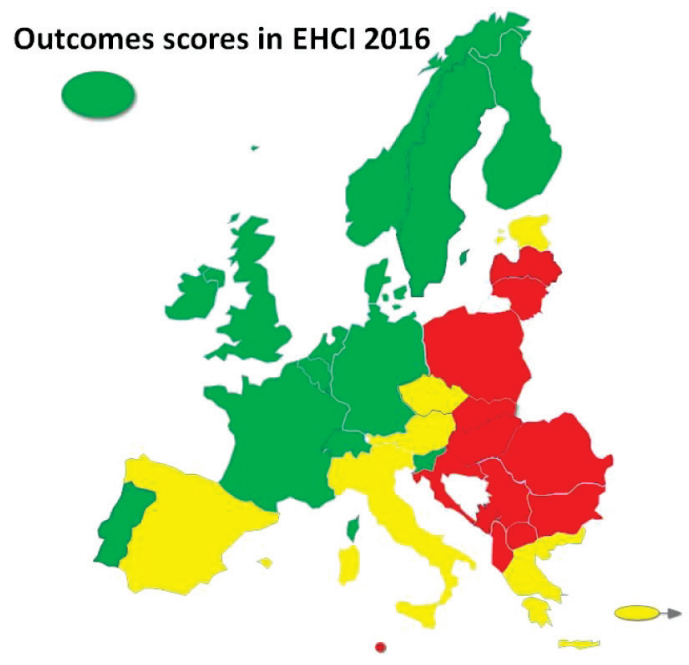

Fig. 1. Quality of healthcare services measured by results of treatment according to EHCI 2015 ranking

Source:[http://www.healthpowerhouse.com/files/EHCI_2016/ EHCI_2016_report.pdf, (12.10.2017)].

According to the above report (data for 2016), Poland is fourth from last in Europe when it comes to the overall assessment of the healthcare system. This assessment consisted of partial assessments of the following areas: patient's rights and access to information, availability of healthcare services (waiting time for treatment), obtained results in treatment, scope of healthcare services, preventing diseases, methods of treatment. Six to twelve subareas were distinguished in particular areas, for instance the availability of healthcare services was assessed through the prism of: access to a family doctor on a given day, direct access to medical specialists, planned surgical operations within up to 90 days, starting cancer therapy within a time shorter than 21 days, computed tomography up to 7 days, waiting time for ad hoc aid (more details [http://www.healthpowerhouse.com/ files/EHCI 2016/EHCI 2016 report.pdf, accessed 11.08.2017]).

In connection with the above, national medical institutions undoubtedly experience the need to search for such methods of management which would make it possible to maximize the degree of use of owned resources and increase the degree of the patients' satisfaction under conditions of limited sources of financing. One of the proposals that appeared in recent years is a change in the approach of the hospital personnel to the patient. According to D. Jones, although good professionals - doctors and nurses - all have contact with the patients only for a short time and they do not wonder "where the patient came from and where the patient needs to go to continue their treatment" [http://lean.org.pl/danjones-w-szczuplych-szpitalach-pacjenci-szybciejzdrowieja/\#l. A comprehensive view of the patient's stay in a hospital is thus necessary, paying attention to where value is created in the treatment process as well as the stages where the highest costs are generated. The assumptions of the Lean Management concept, focused on eliminating bottlenecks and wastage as well as on increasing the quality of provided services, meet such needs of the hospitals. The British experience indicates that the introduction of the concept shortened the time the patient stays in the hospital by half, while the time of diagnosing and starting treatment did not decrease. According to the patients, the quality of the provided services has also improved, and hospitals may handle twice as many patients with the same funds [http://lean.org.pl/leanhealthcare].

\section{Lean Management concept in hospitals}

Lean Management is a notion which appeared in the literature thanks to J.P. Womack and D.T. Jones, D. Roos and J. Krafcik who, at the end of the 1980s, described the experience of Japanese car manufacturers [Womack, Jones 1990]. In their opinion, Lean Management is a concept which makes it possible to improve the quality of implemented processes, but also to develop new ones by using

${ }^{4}$ http://www.healthpowerhouse.com/files/EHCI_2016/EHCI_2016_report.pdf, downloaded on August 11, 2017. 
the owned potential better. It is also identified with actions consisting in eliminating activities that do not add value which the customer is waiting for, but generate costs which are borne by the organization. It is also described as a management philosophy which is based on the cooperation between employees and enables such an organization of the process of delivering goods to the customer which shortens the customer's previous waiting time by eliminating wastage [Łazicki et al. 2011, p. 5]. It is also described as a "lean management system" which may be examined as a set of tools, methods of continuous improvement and commitment of employees, and as a manner of solving problems which are important from the point of view of managers at all management levels [Graban 2011, p. 23]. According to J.K. Liker, the main feature of this concept is the pursuit of resource efficiency and, as a result, the reduction in costs, as well as the improvement in quality and shortening the order implementation time, by means of the consistent elimination of wastage as part of management based on a flat, flexible organizational structure [Liker 2016, p. 6]. Managing an enterprise according to the lean concept is a slow and continuous (never-ending) rationalization process of the entire organization as well as its relations with the environment. It is not a ready-made formula, but rather a general idea for the approach to restructuring the operations of business entities, and its objective is to adjust the enterprise to the market conditions of management by means of deep transformations of the organization and its functioning [Osbert-Pociecha 2007, p. 320]. In the undertaken actions attention is drawn to eliminating any types of wastage, improving the work flow, providing good quality at the first attempt and flexibility in operation. The focus, on the one hand, is on the customer with their individual needs and, on the other hand, on the optimum and continuously improved structure of the enterprise. It is assumed that the Lean concept is applied to improve the effectiveness of functioning by rationalizing the generated costs. It is achieved not by reducing employment or increasing the workload, but rather as a result of greater commitment from all employees to the continuous process of improving the system, based mainly on common sense. Introducing Lean in practice involves a slow, continuous and comprehensive approach to introducing changes in the structure, processes and the manner of organization and management which, in turn, requires changes in people's behavior and attitudes. The concept may also be treated as a restructuring method which introduces such a culture of work to the organization which allows all its members to become interested in the reduction in costs and increasing the quality level so as to meet the customer's expectations as best as possible and prosper by adjusting smoothly to the changing conditions and the requirements of the environment [Womack, Jones 2010, p. 23].

According to $\mathrm{M}$. Graban, an organization of any type, including hospitals, should care about financial liquidity, customer satisfaction and quality [Graban 2011, p. 6]. Problem solving methods developed in production facilities turn out to be an effective tool supporting the functioning of hospitals. Certain similarities in human behavior, as well as similarities in problems and challenges to be met by organizations of any type, are observed. For instance, hospitals face numerous burdensome, long-lasting problems which do not result from the lack of heavy work but from inappropriate management methods. Eliminating them, due to applying the Lean Management concept, most often means a simplification of the processes and a reduction in the employees' effort, a reduction in costs and an improvement in quality [Graban 2011, p. 9]. According to the assumptions of the concept, managers at medical institutions should focus on numerous, minor problems which are easier to be eliminated rather than on complex difficulties, sometimes beyond the control of the managers.

Hospitals began to be interested in "lean management" at the end of the 1990s. Currently, it is possible to indicate examples of the effective improvement of processes which took place in the hospitals and which were based on the assumptions and the introduction of lean tools [http://lean. org.pl]. They include shortening the time of processes significant from the point of view of the patient, savings, improvement in the quality of care and reducing the mortality of patients (see [Graban 2011, p. 7]). According to D. Jones, the Lean Management concept may also be a response to problems in Polish healthcare. In his opinion, the most important thing is to change the way of thinking about the patient. The staff working in the hospital should comprehensively see the patient's stay in the institution, i.e. "where the patient came from and where the patient needs to go to continue their treatment" [http://lean.org.pl]. All activities around the patient are harmonized so that they take place immediately one after another. As a result, the patients do not need to wait for activities which add value in the treatment process and wastage ('muda') is eliminated from the perspective of the hospital's functioning, wastage refers to the time in which activities which do not contribute to providing aid and treating the patients are undertaken (starting from accepting the patients to releasing them) [Graban 
2011, p. 29]. For instance, nurses in numerous hospitals devote only $20-25 \%$ of their working time to the patient, and they spend their remaining time on office activities, moving between various rooms as well as searching for tools and documents etc. [Wiśniewska, Konieczyńska 2011, p. 261].

Improvements introduced as a result of the Lean Management concept relate to the operation of operating theaters, laboratories and X-ray rooms. One searches for ways to simplify the doctors' work, eliminate bottlenecks, and notice possibilities to use the medical equipment better. It is important for employees from various specializations to have the possibility to indicate the possibilities of solving problems. Hospitals may improve the quality of healthcare services as well as improve the processes which lead to areduction in the costs of their functioning for instance, undertaking activities intended to prevent errors. However, we should take into account the fact that introducing the Lean Management concept requires deep cultural, organizationaltechnical changes as well as adjusting the previous management methods in the organization. The concept is often understood instrumentally, people forget that everything starts with "lean thinking" which requires the transformation of thinking, behavior, attitudes and methods of operation of the organization's members on all levels. Using tools without prior changes in the way of thinking and interpersonal contacts makes the concept bring only limited or temporary benefits [Czerska 2009, p. 13]. Moving to new management principles and methods requires a permanent and long-lasting learning process, and new principles of conduct need to be adequately prepared. For this purpose, a thorough analysis of human resources in terms of capacities, skills and predisposition to taking over responsibility and autonomous actions, as well as creativity and readiness to creative operation, is required. The Lean concept involves all participants of the organization in the improvement process and is based on respect for Man, avoiding conflicts and removing their sources which ensures an effective introduction of changes. The literature on the subject [Horbal et al. 2010, pp. 50-67; Teleghani 2010, p. 287; Czerska 2009; Grycuk 2016, pp. 74-78] distinguishes numerous barriers for the implementation of Lean Management. The introduction of the concept is often met with the resistance of employees. The reasons for this phenomenon mainly include fear of change, insufficient knowledge regarding Lean as well as its objectives, lack of trust towards the management staff, as well as bad experiences from the previous implementations of other concepts or initiatives. The managers' poor knowledge on the concept's possibilities from the perspective of increasing the enterprise's effectiveness and competitiveness is also considered an obstacle in developing the concept (see [Błoński, Kondracki 2004, p. 23]). The introduction of Lean Management is also a change of a cultural nature [Lisiński, Ostrowski 2006, p. 154]. In such a situation, it is recommended that the shaping of an appropriate organizational culture (no blame culture), based on openness, trust towards the employees and searching for the possibility to solve the emerging problems, precedes organizational changes [Walentynowicz 2013, p. 127].

\section{Survey results in selected hospitals}

A pilot survey was conducted in two district hospitals located in the Opole voivodeship, in mediumsized towns, in order to examine the possibility of introducing the Lean Management concept. These hospitals provide comprehensive medical services which may be used by the inhabitants of the district. These institutions have a formalized quality management system based on the guidelines of the standard ISO 9001:2008. The hospitals' websites contain their quality policy which states that the most important objective of their operations is to provide medical services which meet the patients' expectations, requirements and needs, and these objectives are implemented by the continuous improvement of management systems, the quality of provided services, the introduction of modern technologies, solving problems in teams, the in-depth analysis of the causes of problems, the systematic improvement of the personnel's qualifications and, in the sphere of hospital nutrition, by the cooperation with suppliers, the monitoring of processes ensuring the appropriate quality of services, compliance with environmental requirements and requirements enabling the production of safe food.

The following wards may be found in the first of the examined hospitals: internal medicine, general surgery, trauma and orthopedic surgery, gynecology and obstetrics, neonatal ward, children's ward, anesthesiology and intensive care, hospital emergency department. The hospital also has a dialysis unit, an operating theater, a central sterile supply department. There also are 15 specialist care clinics and diagnostic laboratories within the hospital. The hospital's work is supported by the operating department, the technical department and the economic-financial department.

The second hospital's structure consists of the following wards: internal medicine, internal medicine and cardiology, general surgery, trauma and orthopedic surgery, gynecology and obstetrics, neonatal ward, 
children's ward, anesthesiology and intensive care, hospital emergency department, infectious diseases and observation, urology, ophthalmology, neurology with a stroke sub-unit, psychiatry, laryngology, fast diagnosis ward. The hospital also has an operating theater as well as rehabilitation, medical imaging and laboratory diagnosis institutions. In the last decade it implemented projects co-financed from EU funds which, according to the managers, significantly improved the quality of treatment.

The self-administered survey technique was used during the research. The employees of the hospital were the respondents of the survey: management, doctors, nurses and auxiliary personnel. The selection was made in an intentional manner. The study covered nine people in total, three people from the top levels of management - the hospital's administration, including the managing director of one of the hospitals, two doctors, three nurses and one person participating in an auxiliary medical process. The research questionnaire was divided into two parts: improvement of hospital processes - current state and the need and potential for introducing the Lean Management concept. In total, thirty-two questions were asked, mainly close-ended, proposing answers to the respondents and not limiting their number. Six questions contained an option enabling to indicate answers other than those suggested, and three questions were open-ended. Among them were: "Please indicate the most important problems (37) faced by the hospital"; "Who could participate in solving these problems?"; "How would you use the results of the patient satisfaction survey?".

The obtained information induces the statement that changes in the examined hospitals are currently not introduced often (once a year, every six months), and one of the examined persons does not notice them at all. The changes are mainly related to processing information and are initiated mostly by the management, sometimes by the quality representative, and there are no bottom-up initiatives. Doctors and nurses are busy with performing current duties and are not involved in improvement actions, they also do not have the possibility to signal the need for changes, but they are looking for the possibility to perform actions in a more precise manner. In turn, the management is focused on searching for different ways of operation, the application of new knowledge and new skills. However, some of the examined people (a head for medical affairs, a doctor and a nurse) are interested in the identification of wastage, while a person not related directly to treatment processes signaled the need to analyze bottlenecks and their opposite in the processes. It may also be noted in the examined entities that, on the one hand, the opinions that the examined hospitals do not have the climate for changes are expressed and, on the other hand, that these changes are necessary. Depending on the occupied position, the reasons for their introduction are different, which is illustrated more precisely in Table 1.

Table 1. Reasons for introducing changes in hospitals

\begin{tabular}{|l|c|c|c|c|}
\hline \multicolumn{1}{|c|}{$\begin{array}{c}\text { Reasons for } \\
\text { introducing } \\
\text { changes } \\
\text { in hospitals }\end{array}$} & $\begin{array}{c}\text { Hospital } \\
\text { management }\end{array}$ & Doctors & Nurses & $\begin{array}{c}\text { Auxiliary } \\
\text { personnel }\end{array}$ \\
\hline $\begin{array}{l}\text { Patients' } \\
\text { expectations and } \\
\text { requirements }\end{array}$ & & $\mathrm{x}$ & $\mathrm{x}$ & $\mathrm{X}$ \\
\hline $\begin{array}{l}\text { Pressure } \\
\text { to improve level } \\
\text { of savings } \\
\text { in hospitals }\end{array}$ & $\mathrm{x}$ & $\mathrm{x}$ & $\mathrm{x}$ & $\mathrm{X}$ \\
\hline $\begin{array}{l}\text { Pressure to reduce } \\
\text { operating costs }\end{array}$ & & $\mathrm{x}$ & $\mathrm{x}$ & $\mathrm{X}$ \\
\hline $\begin{array}{l}\text { Pressure of } \\
\text { general public }\end{array}$ & & $\mathrm{x}$ & $\mathrm{X}$ \\
\hline $\begin{array}{l}\text { Poor financing of } \\
\text { hospital operations }\end{array}$ & & $\mathrm{x}$ & $\mathrm{x}$ & $\mathrm{X}$ \\
\hline $\begin{array}{l}\text { Recommendations } \\
\text { from external } \\
\text { auditors }\end{array}$ & & $\mathrm{x}$ & $\mathrm{x}$ & \\
\hline $\begin{array}{l}\text { Needs submitted } \\
\text { by doctors in } \\
\text { hospitals }\end{array}$ & $\mathrm{x}$ & & $\mathrm{x}$ & \\
\hline $\begin{array}{l}\text { Needs submitted } \\
\text { by nurses }\end{array}$ & & & $\mathrm{x}$ & \\
\hline $\begin{array}{l}\text { Need to shorten } \\
\text { execution time of } \\
\text { activities and } \\
\text { processes }\end{array}$ & & & & \\
\hline $\begin{array}{l}\text { Variability of } \\
\text { environment }\end{array}$ & & & & \\
\hline $\begin{array}{l}\text { Pressure from the } \\
\text { superior institution }\end{array}$ & & $\mathrm{x}$ & \\
\hline $\begin{array}{l}\text { Need to improve } \\
\text { and comunication } \\
\text { between various } \\
\text { parts of hospitals }\end{array}$ & & & & \\
\hline Sorcer & & & & \\
\hline
\end{tabular}

Source: prepared by the authors on the basis of the survey.

The respondents were also asked to specify the barriers in undertaking improvement actions. Persons from the top levels of management indicated the poor creativity of doctors and nurses, while they, on the contrary, indicated the lack of possibility to "break through" with their ideas. The doctors also added the lack of time to search for the possibility to introduce 
changes as well as the lack of funds. The nurses' opinions were similar but they included an opinion suggesting that the management is not searching for knowledge about other methods of work in the hospital. In turn, the representative of the auxiliary personnel, apart from the lack of financial capacity, strongly emphasized the lack of cooperation between all parts of the hospital and the management with one another, which seems to be particularly important from the point of view of the comprehensive look at the patients' stay in a hospital.

The customer plays the most important role in an organization managed in the spirit of lean, and any improvement actions are undertaken in terms of the patient's expectations, preferences and needs. For this reason, the respondents were asked about their opinion on identifying patients with customers. The respondents' opinions on this topic were divided. The examined nurses and the representative of the auxiliary personnel do not agree with such a view at all, while the management rather agrees with this opinion, and there is no agreement in this matter among the doctors. One of the questions also applied to the assessment of the justified nature of examining the degree of the patients' satisfaction with their stay in the hospital. The hospital management believes that such opinions should be collected, analyzed and used to diagnose and solve problems signaled by the patients. The nurses shared this view. They also pointed out the fact that the results of the patients' assessments should be linked with the bonus system. In turn, the doctors' opinions were divided, there is no consensus in this matter.

The respondents could also answer the question about their opinion about introducing a suggestion system, typical of the Lean concept, and placing boxes for cards with ideas in hospitals. Only the managing director stated the feasibility of the idea suggesting such a solution both for the doctors, the nurses and for the patients. The examined doctors, in turn, believed that the management would probably consent to such a solution but there would be no one who could analyze and implement the submitted ideas. The remaining respondents suggested that it would be impossible to introduce such a tool because of the mentality of the staff.

It may be stated that there is potential for changes in the examined entities when assessing the possibility to introduce the Lean concept in these entities. The respondents, at various levels in the hierarchy, feel the need to introduce changes. Both the doctors and the nurses already have ideas for changes. In this situation, it would be worth taking into account the boxes for cards with ideas mentioned in the study, as well as workshops aimed at implementing quick improvements in processes or periodical workshops for process improvement [Graban 2011, p. 252]. Quick small improvements most often bring positive effects and stimulate people to deal with more complex problems. The introduction of the concept, however, requires a change in the way of thinking about processes implemented in organizations. Training enlightening the creation of value expected by the patient as well as the identification and elimination of wastage is important in the initial stages. Currently not all respondents notice the importance of patients in the improvement of processes. In addition it should be pointed out that the introduction of the concept requires the decentralization of organizational power and the significant stimulation of employees. The examined hospitals currently have a high degree of centralization in management. In such a situation, on the one hand, the hospital's administration would need to decide to delegate some of their competences as well as responsibility and, on the other hand, managers would need to take a more active role in popularizing lean management. Their task is to plan the directions of changes, inform the employees about this fact and undertake visible actions [Flinchbaugh 2006 , p. 266]. Visits in gemba (real place) also become significant. These are the places where the processes are actually implemented in hospitals, it is also the observation of places where bottlenecks or their opposite occur. Observing and listening to employees makes it possible to better learn about the actual problems of the hospital and to demonstrate the need for changes.

\section{Conclusion}

Currently, numerous arguments justify the fact that hospitals are paying attention to the possibilities offered by the introduction of the Lean Management concept when they are moving towards an increase in effectiveness. The situation in Polish hospitals has for many years remained unsatisfactory. The managers, while willing to retain medical entities on the market, have been looking for ways to reduce the costs of functioning and, at the same time, maintain a certain quality of the provided services. The problems could not be solved by quick cost cutting, neither by reducing the number of jobs nor limiting the availability of medical services. According to management practitioners [Jones 2015; Graban 2011; Kenney 2011], the Lean Management concept, which has been reserved in the past for manufacturing companies, turns out to be useful in Polish hospitals, which are 
interested in a rational reduction of operating costs, improving the quality of their products and processes, and a strong focus on the needs and expectations of customers, as well as certain financial liquidity. However, one needs to bear in mind the fact that the introduction of the concept requires a change in the method of management, as well as the perception of the organizational reality. Value for the customer, the identification and elimination of any type of wastage, including waiting times, become priorities. When hospitals decide to introduce this concept, they need to take into account the patients' needs, change the way of thinking about the patients, but also consider the readiness of the managers, the doctors and the remaining staff to introduce changes. It will be difficult to introduce any lean change without a strong commitment at all management levels. It is believed that the success of a lean system depends in 80 to $90 \%$ on whether the employees accept the suggested changes, and in $10-20 \%$ on the effective implementation of the appropriate tools [Graban 2011, p. 266]. The declaration not to dismiss employees and making a decision in which areas the process of introducing changes should start also become important in the initial stages. The key role here should be played by the motives for starting actions related to the implementation of lean solutions, which are as follows: the desire to improve quality, reduce the number of amendments, increase the patients' safety (proactive actions), increase the patients' satisfaction, reduce inefficient waiting times for tests, test results or diagnosis, reduce the costs of stock, e.g. medicines, improve the punctuality of auxiliary medical services. It should be taken into account, however, that the present research is preliminary, exploratory, and these characteristics should undoubtedly be considered as the limitation of the study. The conclusions presented in the present paper refer only to the two analysed hospitals.

\section{Bibliography}

Błoński M., Kondracki K., 2004, Zarządzanie na przełomie wieków, Hays Personnel, Warszawa.

Czerska J., 2009, Doskonalenie strumienia wartości, Difin, Warszawa.

Flinchbaugh J., 2006, The Hitchbikers'ss Guide to Lean, Society of Manufacturing Engineers, Dearborn.

Getzen T.E., 2000, Ekonomika zdrowia, PWN, Warszawa.

Graban M., 2011, Lean Hospitals - Improving Quality, Patient Safety, and Employee Satisfaction, Productivity Press Publishing, San Francisco.

Grycuk A., 2016, Bariery w stosowaniu koncepcji Lean Management, Kwartalnik Nauk o Przedsiębiorstwie, nr 3.
Horbal R. et al., 2010, Minione 10 lat ruchu lean w Polsce. Wnioski $i$ perspektywy, [w:] T. Koch (ed.), X Międzynarodowa Konferencja Lean Manufacturing. Materiały konferencyjne, LEIP, Wrocław.

http://lean.org.pl/dan-jones-w-szczuplych-szpitalach-pacjenciszybciej-zdrowieja/\#,accessed 15.08.2017.

http://lean.org.pl/lean-healthcare/, accessed 13.08.2017.

http://www.healthpowerhouse.com/files/EHCI_2016/EHCI_2016_ report.pdf, accessed 11.08.2017.

https://piu.org.pl/wp-content/uploads/2016/12/1_system-opiekizdrowotnej-w-polsce_D.Fal_.pdf, accessed 11.08.2017.

https://piu.org.pl/wp-content/uploads/2016/12/1_system-opiekizdrowotnej-w-polsce_D.Fal_.pdf., accessed 12.08.2017.

Jones T.D., 2015, Four lessons on Lean Healthcare, http://www. leanuk.org/article pages/articles/2015/february/19/four-lessons-on-lean-healthcare.aspx, accessed 26.01.2018.

Jończyk J., 2012, Zmiany w zarzadzaniu zasobami ludzkimi w publicznych szpitalach, [in:] T. Listwan, M. Stor (eds), Sukces w zarzadzaniu kadrami. Elastyczność w zarzadzaniu kapitatem ludzkim, Research Papers of the Wrocław University of Economics no. 248, t 1, Problemy Zarządczo-Ekonomiczne, Wrocław.

Kenney Ch., 2011, Transforming Health Care: Virginia Mason Medical Center's Pursuit of the Perfect Patient Experience, CRC Press, San Francisco.

Liker J.K., 2016, Droga Toyoty. 14 zasad zarzadzania wiodacej firmy produkcyjnej świata, MT Biznes, Warszawa.

Lisiński M., Ostrowski B., 2006, Lean Management w restrukturyzacji przedsiębiorstwa, Antykwa, Kraków- Kluczbork.

Ludwiczak A., 2017, Pozyskiwanie informacji od klienta w ksztattowaniu jakości ustug zdrowotnych w ujęciu procesowym, [in:] S. Nowosielski, G. Osbert-Pociecha (eds), Nowe kierunki w zarządzaniu przedsiębiorstwem. Procesy i projekty w zarządzaniu zmianami, Wydawnictwo Uniwersytetu Ekonomicznego we Wrocławiu, Wrocław.

Łazicki A. et al., 2011, Systemy zarządzania przedsiębiorstwem: techniki Lean Management i Kaizen, Wydawnictwo Wiedza i Praktyka, Warszawa.

Osbert-Pociecha G., 2007, Lean Management jako ogólna koncepcja transformacji przedsiębiorstw, [in:] J. Lichtarski (ed.), Podstawy nauki o przedsiębiorstwie, Wydawnictwo Akademii Ekonomicznej we Wrocławiu, Wrocław.

Raport EHCI 2016, https://piu.org.pl/wp-content/uploads/2016/12/ 1_system-opieki-zdrowotnej-w-polsce_D.Fal_.pdf. 9, accessed 12.10.2017.

Raport Najwyższej Izby Kontroli „Realizacja zadań Narodowego Funduszu Zdrowia w 2015 r.”, www.nik.gov.pl/plik/id,7653, vp,9595.pdf., accessed 10.09.2017.

Szewieczek A., 2013, Lean Management jako innowacja zarzad$c z a$ w szpitalu, Zeszyty Naukowe Uniwersytetu Szczecińskiego nr 786, Finanse, Rynki Finansowe, Ubezpieczenia nr 64/1, Szczecin.

Teleghani M., 2010, Key factors for implementing the lean manufacturing system, Journal of American Science, no. 6.

Ustawa z dnia 15 kwietnia 2011 r. o działalności leczniczej, Dz.U. nr 112, poz. 654 ze zmianami w 2016, poz. 960.

Walentynowicz P., 2013, Uwarunkowania skuteczności wdrażania Lean Management w przedsiębiorstwach produkcyjnych w Polsce, Wydawnictwo Uniwersytetu Gdańskiego, Gdańsk.

Wiśniewska M., Konieczyńska E., 2011, Lean management narzędziem doskonalenia zarządzania szpitalem, Studia i Materiały Polskiego Stowarzyszenia Zarządzania Wiedzą, no. 54, 
Bydgoszcz, http://www.pszw.edu.pl/pl/publikacje/item/924-tomt054-11, accessed 15.09.2017.

Womack J.P., Jones D.T., 1990, The Machine that Changed the World, Macmillan, New York.

Womack J.P., Jones D.T., 2008, Lean thinking - szczupte myślenie: eliminowanie marnotrawstwa $i$ tworzenie wartości w przedsiębiorstwie, ProdPress.com, Wrocław.
Womack J.P., Jones D.T., 2010, Szczupte rozwiązania, czyli jak przedsiębiorstwa i ich klienci moga pomnażać korzyści ze wzajemnej wspótpracy stosujac zasady Lean Management, Wydawnictwo Lean Enterprise Institute Polska, Wrocław.

\section{KONCEPCJA LEAN MANAGEMENT W ZARZADDZANIU SZPITALAMI - MOŻLIWOŚCI I OGRANICZENIA}

Streszczenie: W artykule, nawiązując do aktualnej sytuacji krajowych publicznych placówek szpitalnych, zaprezentowano możliwości zastosowania koncepcji Lean Management w zarządzaniu nimi. Wskazano na wiele cech wspólnych, łączących zarządzanie podmiotami komercyjnymi z podmiotami leczniczymi. Stwierdzono, że we współczesnych organizacjach, niezależnie od rodzaju prowadzonej działalności, zarządzanie musi być ukierunkowane na zadowolenie klientów/pacjentów, płynność finansową i wysoką jakość. Celem artykułu jest ocena możliwości zastosowania koncepcji Lean Management w placówkach szpitalnych. Przede wszystkim na podstawie pilotażowego badania ankietowego podjęto próbę oceny wprowadzenia powyższej koncepcji w wybranych dwóch szpitalach. Do realizacji tak określonego celu wykorzystano metodę krytycznej analizy literatury przedmiotu, wywiad nieustrukturyzowany, obserwację praktyki, a także badanie ankietowe opierające się na przygotowanym kwestionariuszu.

Słowa kluczowe: Lean Management, Lean Health Care, doskonalenie procesów. 